\title{
Design of a single-acting ammonia-water solar absorption cooling system for food preservation
}

\section{Diseño de un sistema de refrigeración por absorción solar amoniaco-agua de simple efecto para la conservación de alimentos}

\author{
HERNÁNDEZ-GÓMEZ, Víctor Hugo†*, OLVERA-GARCÍA, Omar, DE LA ROSA-FLORES, Yarabi \\ and SÁNCHEZ-BARRERA, Iveth
}

Universidad Nacional Autónoma de México, FES Cuautitlán, State of Mexico, Mexico.

ID $1^{\text {st }}$ Author: Víctor Hugo, Hernández-Gómez / ORC ID: 0000-0001-9315-5869, Researcher ID Thomson: S-6575-2018, CVU CONACYT ID: 122247

ID $1^{\text {st }}$ Coauthor: Omar, Olvera-García / ORC ID: 0000-0001-6386-9772, Researcher ID Thomson: S-6644-2018, CVU CONACYT ID: 706478

ID $2^{\text {nd }}$ Coauthor: Yarabi, De la Rosa-Flores / ORC ID: 0000-0003-2173-0750, CVU CONACYT ID: 1045334

ID $3^{\text {rd }}$ Coauthor: Iveth, Sánchez-Barrera / ORC ID: 0000-0003-0438-1296, CVU CONACYT ID: 1045331

DOI: $10.35429 / J T D .2020 .13 .4 .1 .9$

Received: January 10, 2020; Accepted June 30, 2020

\begin{abstract}
The increase in the use of non-renewable energy sources and the strong dependence of the energy sector on these sources, encourage the study of applications that use renewable energy sources. In this scenario, there has been an increase in the number of jobs related to refrigeration systems that use other sources of energy in addition to electricity, such as absorption cooling systems, which can produce a cooling effect using mainly heat. residual or other sources such as solar thermal energy. This article presents the design of a cooling system that will operate with solar energy, using the principle of absorption with the ammonia-water working torque in continuous function, to contribute to a cold production alternative in food preservation.
\end{abstract}

Absorption cooling, Ammonia-water, Thermal load

\begin{abstract}
Resumen
El creciente aumento en el uso de fuentes de energía no renovables y la fuerte dependencia del sector energético a dichas fuentes, incentivan el estudio de aplicaciones que utilizan fuentes de energía renovables. En ese escenario, se ha observado en los últimos años un aumento en el número de trabajos relacionados con sistemas de refrigeración que utilizan otras fuentes de energía además de la eléctrica como los sistemas de refrigeración por absorción, los cuales pueden producir efecto frigorífico usando principalmente calor residual o de otras fuentes como la energía solar térmica. En el presente artículo se presenta el diseño de un sistema de refrigeración que operará con energía solar, empleando el principio de absorción con el par de trabajo amoníaco-agua en función continua, para contribuir con una alternativa de producción de frio en la conservación de alimentos.
\end{abstract}

Refrigeración por absorción, Amoniaco-agua, Carga térmica

Citation: HERNÁNDEZ-GÓMEZ, Víctor Hugo, OLVERA-GARCÍA, Omar, DE LA ROSA-FLORES, Yarabi and SÁNCHEZ-BARRERA, Iveth. Design of a single-acting ammonia-water solar absorption cooling system for food preservation. Journal of Technological Development. 2020. 4-13:1-9.

\footnotetext{
* Correspondence to the author (Email: vichugo@unam.mx).

$\uparrow$ Researcher contributing as first author.
} 


\section{Introduction}

In recent years, the global elimination of CFC, HCFC and HFC refrigerant gases has been negotiated, due to their potential impact on the degradation of the ozone layer and global warming. However, these substances are essential in current refrigeration systems, being an extremely important process in modern society, as it is essential for the preservation of food, industrial processes and in air conditioning. Faced with this scenario, an increase in the number of jobs related to refrigeration systems that use other sources of energy in addition to electricity, such as absorption refrigeration systems (Pérez, 2014), has been observed in recent years, which can produce refrigeration effect using mainly residual heat or other sources such as solar thermal energy (Ruíz, 2011; Moreno, 2018).

Absorption cooling is presented as an option for refrigeration systems for product preservation purposes, since low temperatures allow the effects of chemical and enzymatic reactions to be slower, and the growth of some bacteria is limited (López, J. 2012). The Ammonia-Water (NH3-H2O) absorption cycle is a technology in extensive development and experience during the early years of the refrigeration industry, particularly for ice making. Likewise, the low to moderate temperatures necessary for its operation and the independence of electrical energy sources, make the absorption cycle a good candidate to be used in conjunction with solar energy (Esquivel, 2006).

In this work, each stage that involves the design of an adsorption cooling system for the NH3-H2O pair is shown and described, which will produce the cooling effect by taking advantage of the thermal energy from the sun and will be used for food preservation.

Absorption is a process in which two fluids that enter different states, such as a gas or liquid, combine to exit in a single state, either as a gas or liquid (Dincer, 2016). The mixtures used in these machines are composed of a solvent and a refrigerant fluid that, at a certain point in the cycle, is absorbed by the solvent (hence the name), and at another point is separated from the solvent.
In order to obtain this result, it is necessary that the solvent, when cold, has an affinity for the refrigerant fluid; when the temperature of the mixture rises, this affinity decreases, releasing the refrigerant fluid from the solvent (Rapin, 1976).

A basic absorption refrigeration system consists of a generator, absorber, condenser, evaporator, pump, and expansion valves. Figure 1 shows the operation of a basic refrigeration system.



Figure 1 Ciclo de refrigeración por absorción Source: Modified from Dincer, 2016

In Figure 1 it is observed that, in the evaporator, the saturated refrigerant mixture gains heat from the cooled space and leaves (1) to enter the absorber. The weak solution that returns from the generator passes through an expansion valve where its pressure drops to exit (8) and enter the absorber. The weak solution and the refrigerant mix in the absorbent and reject the heat of the cooling fluid to leave it as a strong solution in liquid form (2). The strong solution exiting the absorber (2), first passes through the pump, where the pressure of the strong solution increases before it enters the generator (3). The heat is supplied to the generator where the strong solution is heated (3) to separate the refrigerant. The vaporized refrigerant leaves the generator (4) and enters the condenser where it rejects the heat to the refrigerant fluid to leave it (5) as a saturated mixture, while the weak solution leaves the generator to enter the absorber (7). The saturated mixture then passes through the expansion valve where its pressure drops suddenly to increase the vapor content in the saturated mixture where it enters the evaporator (6). (Dincer, 2016). 
The selected working pair is a mixture of ammonia in water, the combinations in different proportions still retain their individual characteristics, that is, components of this mixture can be physically separated, without the need to break any chemical bonds (Church \& Dwight Co. Inc. ., 2007), and its TEWI value (Total Equivalent Heating Impact) of ammonia is very low, due to its favorable thermodynamic characteristics and that less energy is used than other refrigerants (Sans, 1989; Ruíz, 2011; Miranda, 2012) .

It is also called aqueous ammonia (concentrated aqueous dilution of ammonia), these dilutions can be prepared at different concentrations. The advantage of its use compared to anhydrous ammonia (100\% ammonia) is the simplicity of handling and the elimination of most of the dangers that the gaseous form presents (Navarro, 2014).

The absorption system is based on the fact that the vapors of some refrigerants can be absorbed in large quantities by certain liquids. The refrigerant can be separated from the solution resulting from the absorption by heating. Therefore, the absorption cycle replaces the compressor with the generator-absorber assembly and the pump, while the evaporator, the condenser and the expansion valve work in the same way as in the compression cycle.

\section{Background}

Progress and work on absorption refrigeration systems in recent years are presented in order to present the progress that has been made:

Francisco et. to the. (2002) developed and tested a prototype of absorption refrigeration using ammonia-water, powered by solar energy to operate in rural areas with a refrigeration capacity of $2 \mathrm{~kW}(7.2 \mathrm{MJ})$. This small-scale prototype is designed for continuous operation and the necessary energy is obtained from a parabolic cylindrical collector that reaches temperatures above $150^{\circ} \mathrm{C}$. Mauricio Canadas. et al (2010), made a design of an absorption refrigerator for educational use, deducing that an absorption cycle operated by solar energy is technically feasible by conventionally modifying the cycle, with regard to operating temperatures, especially in the generator., with the aim of using flat plate solar collectors as a heat source.
Labus M. J. (2013) developed a prototype of an NH3-H2O absorption heat pump designed to operate with a parabolic solar collector, the inlet temperature of the generator is $90{ }^{\circ} \mathrm{C}$. Typical COP values for the cooling mode were in the range of $0.58-0.8$ and $1.5-1.8$ for the heating mode. Due to the minimum temperature reached in the evaporator of $3^{\circ} \mathrm{C}$, the authors recommended the use of the system for food preservation and for air conditioning.

Catota, P. \& Tonato, W. (2015). They designed and implemented a prototype of intermittent ammonia-water absorption solar cooling, in which it was possible to obtain temperatures between $10-16^{\circ} \mathrm{C}$ for a short operating time, using an electrical resistance of $120 \mathrm{~W}$ that allows Take advantage of the solar energy converted by photovoltaic panels. They determined that the concentration of ammonia in the working solution is the most important factor that must be taken into account, because in a solution poor in ammonia the temperatures required for steam generation are higher to reach the working pressure in the system.

\section{Prototype design}

The system was designed using ammonia-water as a working pair in one stage and continuous operation, employing a parabolic trough concentrator with which the thermal energy (solar radiation) necessary to achieve cooling was supplied. The project is being developed at the Cuautitlán School of Higher Studies, field 4, of the National Autonomous University of Mexico.

A load of $22 \mathrm{lb}$ of product was considered, which will enter at a temperature of $77^{\circ} \mathrm{F}$ and decrease until the storage temperature of $32^{\circ} \mathrm{F}$, estimating an operating period of $8 \mathrm{~h}$.

For the design conditions, the food that provides the highest amount of heat, the highest heat capacity $(\mathrm{Cp})$ and the lowest storage temperature was considered, since in this way it is ensured that the other products will be close to their storage temperature. 
To calculate the heat that must be removed or eliminated from the chamber and thereby maintain the interior design temperature, the method developed by the American Association of Refrigeration, Heating and Air Conditioning Engineers "American Society of Heating, Refrigeration and Air-Conditioning Engineers ", (ASHRAE) based on the conditions in table 1 .

\begin{tabular}{|c|c|c|}
\hline \multicolumn{3}{|l|}{ Initial conditions } \\
\hline Application & Value & Units \\
\hline Refrigerated zone size & 8.4 & $\mathrm{ft}^{2}$ \\
\hline Air volume & 1.59 & $\mathrm{ft}^{3}$ \\
\hline Storage quantity & 22.04 & $\mathrm{lb}$ \\
\hline Chamber temperature & 23 & ${ }^{\circ} \mathrm{F}$ \\
\hline Storage temperature & 32 & ${ }^{\circ} \mathrm{F}$ \\
\hline Temperature at which the product is & 77 & ${ }^{\circ} \mathrm{F}$ \\
\hline Room temperature & 77 & ${ }^{\circ} \mathrm{F}$ \\
\hline Temperature difference & 77 & ${ }^{\circ} \mathrm{F}$ \\
\hline Working hours (storage) & 8 & $\mathrm{~h}$ \\
\hline Condensing temperature & 86 & ${ }^{\circ} \mathrm{F}$ \\
\hline
\end{tabular}

Table 1 Initial design conditions Source: ASHRAE

Thus, obtaining the total thermal load with the following balance:

$Q_{\text {evaporator }}=$ Qstructure + QProduct + Qleakages + Qlighting

Table 2 summarizes the total load per day and hour of work, in addition, $10 \%$ was considered as a safety factor added to the total refrigeration load, to consider the minimum omission or inaccuracy (Dossat, 2002).

\section{Calculation of system flows and heats}

For the prototype design, six main components were considered: evaporator, absorber, recirculating pump, rectifier, condenser and expansion valve. Its distribution and conformation is represented in Figure 2.

\begin{tabular}{|c|c|c|}
\hline Loads & $\mathbf{Q}$ & Units \\
\hline Thermal load of the structure & 388.643 & BTU / day \\
\hline Thermal load by the product & 2350.566 & BTU / day \\
\hline $\begin{array}{l}\text { Thermal load due to } \\
\text { infiltration }\end{array}$ & 1.347 & BTU / day \\
\hline Charge for lighting & 68.243 & BTU / day \\
\hline Sum of loads & 2808.799 & BTU / day \\
\hline $\mathrm{Q}+10 \%$ & 3089.678 & BTU / day \\
\hline \multirow{3}{*}{$\begin{array}{l}\mathrm{Q} \text { total }(\mathrm{Q}+10 \% / \text { working } \\
\text { hours })\end{array}$} & 386.211 & BTU / h \\
\hline & 0.032 & TR \\
\hline & 112 & W \\
\hline
\end{tabular}

Table 2 Summary of thermal loads and total load Source: Own elaboration



Figure 2 Simple effect ammonia-water absorption cooling system

Source: Own, AutoCAD 2018

Figure 2 represents the proposed design for this refrigeration system, where the process conditions are presented to establish the flows of each component.

Starting from the heat flow equation, the material and energy balances were carried out starting with the evaporator.

$Q=\dot{m} \Delta h$

Considering an analysis of the first law of thermodynamics, the mass flows of each component were calculated.

Input $=$ Output

$M_{7}=M_{1}$

Calculating the mass flow in the evaporator:

$\dot{m}=\frac{Q}{\Delta h}=\frac{Q}{\left(h_{1}-h_{7}\right)} l b / h$

To determine the mass flows that are not known, the mass balances were carried out in the different components according to the design conditions (Figure 2).

\section{Balance in absorber}

$M_{1}+M_{2^{\prime}}=M_{3}$

By fractions:

$M_{1} X_{1}+M_{2^{\prime}} X_{2^{\prime}}=M_{3} X_{3}$

$M_{3}=\frac{M_{1} X_{1}-M_{1} X_{2}}{\left(X_{3}-X_{2}^{\prime}\right)}$

$M_{2 "}=M_{3}-M_{1}$ 
It is further considered that:

$M_{2^{\prime}}=M_{2}$

\section{Balance in Condenser}

$M_{6}=M_{7}$

$\mathrm{Y} M_{7}=M_{1}$

\section{Balance in the Generator-Rectifier}

$M_{3}+M_{5}=M_{2}+M_{4}$

For M_5, a reflux ratio of 0.341 is considered, therefore:

$M_{5}=0.341 * M_{6}$

Therefore:

$M_{4=} M_{5}+M_{2}$

To carry out the energy balance, it was necessary to determine the enthalpies of each point of the system, using the enthalpyconcentration diagram of the ammonia-water mixture originally presented by Merkel and Bosnjakovic, which allows direct reading of the enthalpy difference.

It includes in its lower part, isobar and isotherm networks, as well as liquid vapor equilibrium curves in equal concentrations. In the upper part, the reference curves allow to establish the characteristics of the vapor phase, starting from a certain equilibrium point in the lower part (Kherris, S., 2013). To determine the enthalpy, we enter with the concentrations obtained from the mass balance on the "x" axis, we enter with a vertical line up to the pressure at which it is being evaluated and finally with a horizontal line up to the "y" axis where the enthalpy can be read, this can be seen in Figure 3 .

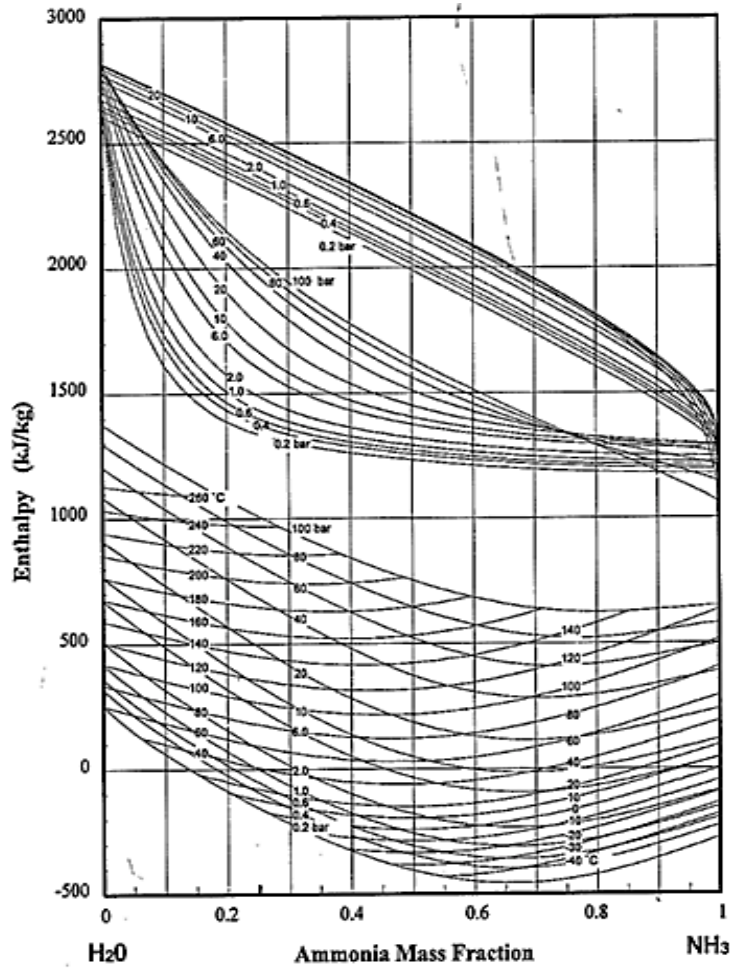

Figure 3 Enthalpy-concentration diagram of the ammonia-water mixture

Source: Herold, 1996

Table 3 presents the results of the balances.

\begin{tabular}{|c|c|c|c|c|}
\hline Component & $\underset{(\mathbf{l b} / \mathbf{h})}{\mathbf{m}}$ & Fraction & Value & $\begin{array}{c}\mathbf{Q} \\
(\mathrm{BTU} / \mathrm{h})\end{array}$ \\
\hline \multirow{2}{*}{$\begin{array}{l}\text { M1 } \\
\text { (Evaporator) }\end{array}$} & \multirow[t]{2}{*}{0.761} & $\mathrm{X}_{1(\mathrm{NH} 3)}$ & 0.987 & \multirow[t]{2}{*}{386.2098} \\
\hline & & $\mathrm{X}_{1(\mathrm{H} 2 \mathrm{O})}$ & 0.013 & \\
\hline \multirow{2}{*}{$\begin{array}{l}\text { M2 (Return to } \\
\text { absorber) }\end{array}$} & \multirow[t]{2}{*}{1.142} & $\mathrm{X}_{2(\mathrm{NH} 3)}$ & 0.259 & \multirow[t]{2}{*}{1302.8723} \\
\hline & & $\mathrm{X}_{2(\mathrm{H} 2 \mathrm{O})}$ & 0.741 & \\
\hline \multirow[t]{2}{*}{ M3 (Power) } & \multirow[t]{2}{*}{1.904} & $\mathrm{X}_{3(\mathrm{NH} 3)}$ & 0.55 & \multirow[t]{2}{*}{--} \\
\hline & & $\mathrm{X}_{3(\mathrm{H} 2 \mathrm{O})}$ & 0.45 & \\
\hline \multirow[t]{2}{*}{ M4 (Distilled) } & \multirow[t]{2}{*}{1.021} & $\mathrm{X}_{4(\mathrm{NH} 3)}$ & 0.987 & \multirow[t]{2}{*}{1141.4688} \\
\hline & & $\mathrm{X}_{4(\mathrm{H} 2 \mathrm{O})}$ & 0.013 & \\
\hline \multirow[t]{2}{*}{ M5 (Reflux) } & \multirow[t]{2}{*}{0.260} & $\mathrm{X}_{5(\mathrm{NH} 3)}$ & 0.987 & \multirow[t]{2}{*}{--} \\
\hline & & $\mathrm{X}_{5(\mathrm{H} 2 \mathrm{O})}$ & 0.013 & \\
\hline \multirow{2}{*}{$\begin{array}{l}\text { M6 = M7 } \\
\text { (Capacitor) }\end{array}$} & \multirow[t]{2}{*}{0.761} & $\mathrm{X}_{6(\mathrm{NH} 3)}$ & 0.987 & \multirow[t]{2}{*}{333.8320} \\
\hline & & $\mathrm{X}_{6(\mathrm{H} 2 \mathrm{O})}$ & 0.013 & \\
\hline
\end{tabular}

Table 3 Results of the balance of matter and energy Source: Own elaboration

\section{Design of the components of the absorption system}

From the material and energy balances carried out, the transfer area was calculated to determine the dimensions, finally the designs for the evaporator, condenser, absorber and rectifier were proposed, which are described below. 


\section{Evaporator}

Features:

\section{Length: $98.75 \mathrm{ft}$}

Pipe Diameter: 3/8 ", 3003 Flexible Aluminum.

Pressure: 3.64 bar.

Cold Chamber: 19.69 x 11.81 x 14.22 i

Interior: 22 gauge aluminum foil.

Insulator: 6.3 in. Expanded polystyrene.

Figure 4 shows the evaporator.



Figure 4. Evaporator proposal

Source: Own source, SolidWorks 2017

\section{Condenser}

\section{Features:}

Length: 4,265 ft.

Tubing: 3/8 ", 316 stainless steel.

Fins: Aluminum.

Pressure: 11.67 bar.

Figure 5 shows the capacitor.

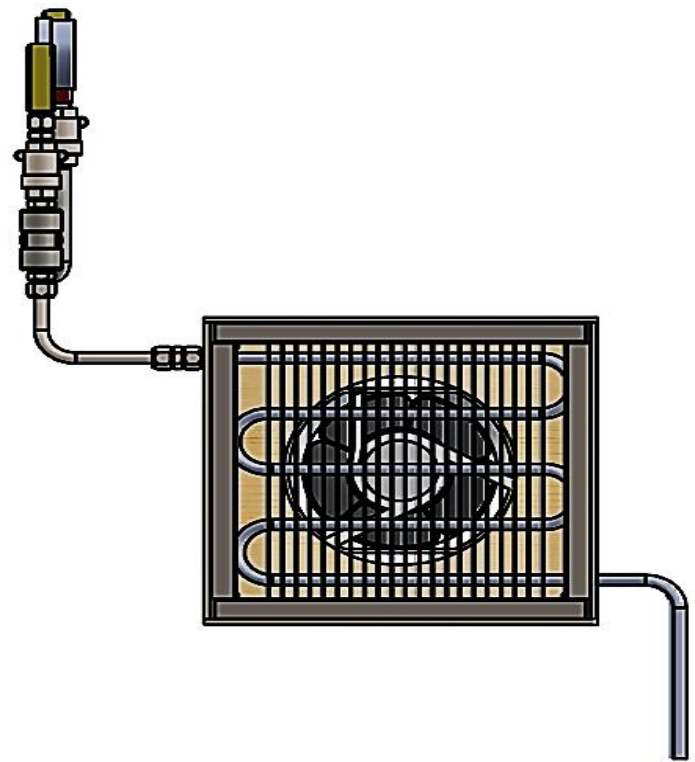

Figure 5 Condenser proposal

Source: Own source, SolidWorks 2017

\section{Absorber}

Features:

vtotal $+20 \%: 0.37 \mathrm{ft}^{3} /$ day.

Length: $1.067 \mathrm{ft}$.

Body: 304 stainless steel, 9 in.

Pressure: 3.64 bar.

Mixing volume (NH3-H2O): $0.309 \mathrm{ft} 3$ / day. Accessory: 304 stainless steel sprinkler, $1 / 4$ in The absorber is shown in Figure 6.

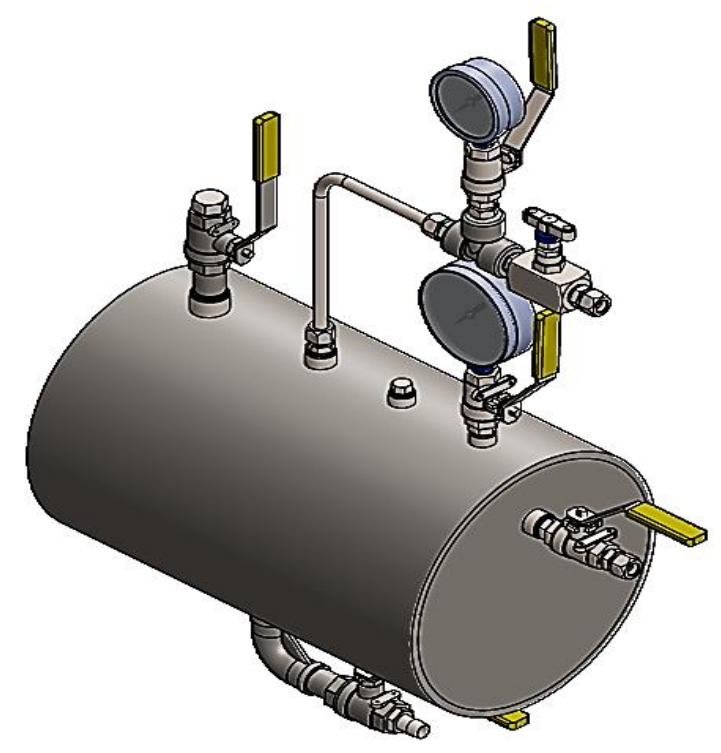

Figure 6 Absorber proposal

Source: Own source, SolidWorks 2017 


\section{Rectifier}

Features:

Body: 316 stainless steel, 4 in.

Pot: $3 / 8$ in, 316 stainless steel.

Length: $1.6404 \mathrm{ft}$.

Condenser: 3/8 ", 316 stainless steel.

Pressure: 11.67 bar.

Packaging: glass.

Stages: 1 and a boiler.

Figure 7 shows the rectifier.



Figure 7 Rectifier proposal

Source: Own source, SolidWorks 2017

To drive the saturated mixture from the absorber to the rectification tower, a centrifugal pump for corrosive liquids brand Little Giant, model 1-MD of 1/70 HP and RPM 2450-2250 is used.

\section{Instrumentation}

The distribution of each connection and instrument is shown in Figure 8 and the specifications in a summarized way are shown in Table 4.



Figure 8 Connection and instrumentation of the prototype Source: Own source. Microsoft Visio, 2019

\begin{tabular}{|c|c|c|c|}
\hline Code & Name & Quantity & Specs \\
\hline VP & Gate valve & 13 & $\begin{array}{l}\text { Connection: } 3 / 8 \\
\text { and } 1 / 4 \quad \text { in } \\
\text { Material: } \\
\text { Stainless steel, } \\
316 \text { Pressure: } \\
1000 \text { WOG }\end{array}$ \\
\hline VE & $\begin{array}{l}\text { Expansion } \\
\text { valve }\end{array}$ & 2 & $\begin{array}{l}\text { Connection: } 3 / 8 \\
\text { in Material: } \\
\text { Stainless Steel, } \\
316 \text { Pressure: } \\
6000 \quad \text { PSI } \\
\text { Pressure Range: - } \\
30 \text { inHg to } 150 \\
\text { PSI }\end{array}$ \\
\hline $\mathrm{MA}$ & $\begin{array}{l}\text { High } \\
\text { pressure } \\
\text { gauge }\end{array}$ & 2 & $\begin{array}{l}\text { Connection: } 1 / 4 \text { in } \\
\text { Material: } 316 \\
\text { Stainless Steel } \\
\text { Pressure Range: - } \\
30 \text { inHg to } 300 \\
\text { PSI }\end{array}$ \\
\hline MB & $\begin{array}{l}\text { Low } \\
\text { pressure } \\
\text { gauge }\end{array}$ & 3 & $\begin{array}{l}\text { Connection: } 1 / 4 \text { in } \\
\text { Material: } 316 \\
\text { stainless steel }\end{array}$ \\
\hline
\end{tabular}

Table 4 Specifications of the connections and instrumentation of the prototype

Source: Own elaboration

\section{Advance}

The prototype design is in place and is currently under construction. After that, hydrostatic tests will be carried out on components such as the absorber and rectifier to determine whether or not they present leaks. Finally, each component of the system will be assembled using pipes and the necessary connections, with this, the designed prototype will finally be obtained, which will once again be carried out the same test to identify leaks within the entire system before starting it up.

Once it is ensured that the prototype does not have leaks, the equipment will be tested, for which, enough refrigerant (Ammonia) has already been purchased to start it up. During these tests, the temperature inside the cold chamber is monitored during the 8 hours of operation for which it was designed and the temperature of the water vapor that will feed the rectifier (boiler). With these results, the thermal history will be obtained that will allow us to determine what are the operating conditions under which the system can operate so that it is suitable for preserving food. 
It is expected that with the results obtained from this project, it will be possible to have a functional alternative of an environmentally-friendly refrigeration system, which uses solar energy that works with a natural refrigerant that does not generate any environmental impact, but that it considers in the future be totally independent of electrical energy consumption.

\section{Acknowledgment}

We thank the National Autonomous University of Mexico for the support received for the implementation of the project, through the programs UNAM-DGAPA-PAPIME-PE101218 and PIAPI2023.

\section{Conclusions}

Absorption systems are technology that boomed again in recent years because it can work by taking advantage of residual energy and mainly solar energy. These systems, unlike compression equipment, require less maintenance, lower energy consumption, lower noise generation, but above all they have less environmental impact. The prototype was designed to be used in the conservation of food at a temperature of $32^{\circ} \mathrm{F}$ which is considered to use the materials with which they are available in the research laboratory in renewable energies and has the characteristic of being fed with different sources of heat. It will not limit its operation since it is independent of any solar energy collection equipment.

It is intended to be part of the transition in the refrigeration industry towards the use of clean energy and natural refrigerants.

\section{References}

Catota, P. \& Tonato, W. (2015). Diseño y construcción de un prototipo de refrigeración solar por absorción mediante par amoníaco agua para la conservación de alimentos. Tesis de licenciatura. Universidad de las Fuerzas Armadas.

Compañía Church \& Dwight Co. Inc. (2007). Hoja informativa sobre las medidas de seguridad. Hidróxido de amonio. Princeton, USA.
Dincer I., Hussain T. (2016). Integrated absorption refrigeration systems: Comparative Energy and Exergy Analyses. Springer.

Dossat R. (2002). Principios de Refrigeración. México: Continental.

Esquivel O., Busso A., Sogari N., Franco J. (2006). Refrigeración solar mediante ciclo de amoniaco-agua acoplado a un concentrador solar. Comunicaciones Científicas y tecnológicas, Universidad Nacional del Nordeste, Argentina.

Herold K., Radermacher R. \& Klein S. (1996). Absorption Chillers and Heat Pumps. Florida, EE. UU: CRC Press.

Kherris, S., Makhlouf M., Zebbar D. (2013). Contribution study of the thermodynamics. Properties of the ammonia-water mixtures. Thermal science. 17: 891-902.

Labus M. J., Bruno J. C. \& Coronas A. (2013). Review on absorption technology with emphasis on small capacity absorption machines. Thermal Science. 17: 739-762.

López, J. (2012). Proceso de conservación de alimentos. ( $3^{\mathrm{a}}$ ed.). México: Colegio de Bachilleres del Estado de Sonora.

Miranda A. (2012). Manual técnico de refrigerante. España: Marcombo.

Moreno D., Ferro V., De Riva J., Santiago R., Moya C., Larriba M. \& Palomar J. (2018). Absorption refrigeration cycles based on ionic liquids: Refrigerant/absorbent selection by thermodynamic and process analysis. Applied Energy. 213: 179-194.

Navarro G. \& Navarro S. (2014). Fertilizantes: química y acción. España: Mundi-Prensa.

Pérez R, Eduar E. (2014). Diseño y construcción de un sistema de refrigeración por adsorción química a partir del uso de energía solar.

Rapin, J. (1976). Instalaciones Frigoríficas. (Tomo 2). España: Boixareu. 
Ruíz, L. (2011). Amoníaco. Ventajas ambientales. Revista Mundo HVAC\&R. Recuperado el 16 de enero de 2018 de https://www.mundohvacr.com.mx/mundo/2011 /05/amoníaco-ventajas-ambientales/

Sans R. \& Ribas J. (1989). Ingeniería ambiental: contaminación y tratamientos. España: Marcombo. 